\title{
Spectrum of renal lesions encountered in a rural setup over a period of five years
}

\author{
Savita .D ${ }^{1}$, Raja Parthiban ${ }^{2, *}$, Abhishek $\mathbf{A}^{3}$ \\ ${ }^{\mathbf{1}}$ Assistant Professor, ${ }^{2}$ Professor and HOD, ${ }^{3}$ Post Graduate, Dept. of Pathology, M V J Medical College and Research Hospital, \\ Bangalore, Karnataka, India
}

*Corresponding Author:

Email: indianpathology@gmail.com

\begin{abstract}
Kidney is involved in many pathological conditions which include both non-neoplastic and neoplastic lesions; some of lesions may require nephrectomy. ${ }^{1}$ Knowledge of a disease pattern in the local population is important to monitor the people at risk and to impart valuable information to treat patients as well as to implement various health programmes.

Aim: To analyze the pattern of the renal disease encountered at a tertiary rural hospital setup and to compare these findings with studies done in other parts of India and other neighboring countries where data is available.

Materials and Methods: A 5 year retrospective and prospective analysis of renal specimen received from Jan 2012 - Dec 2017. Relevant clinical data, gross, microscopic findings were collected and analyzed. Core needle biopsy samples and pelvi-uretric junction specimens were excluded from the study.

Result: Most common lesions encountered were non-neoplastic (55.3\%), of which a majority were chronic pyelonephritis (26.3\%). Neoplastic lesion accounted for $44.7 \%$ of which $28.9 \%$ were malignant neoplasms. Most common age group was 50-60 years followed by $40-50$ years for all the lesions. Hydatid cyst kidney, Solitary fibrous tumor \& transitional cell carcinoma in kidney were some rare lesions encountered.

Conclusion: Non-neoplastic conditions like chronic pyelonephritis were the common renal conditions observed. Implementation of health education and screening programmes including management of common conditions like diabetes mellitus, hypertension, and renal calculi will definitely reduce the indication for nephrectomies. This baseline data can be utilized for further studies in future.
\end{abstract}

Keywords: Nephrectomy, Pyelonephritis, Renal cell carcinoma, Solitary fibrous tumor.

\section{Introduction}

Nephrectomy is a common surgical procedure which is done for a variety of neoplastic and nonneoplastic conditions. Histopathology is gold standard for diagnosing various renal disorders. The common non-neoplastic diseases, for which nephrectomy is usually performed are non-functioning kidney in relation to hydronephrosis, pyonephrosis, polycystic kidneys etc. It is also the standard of care for patients with suspected renal tumors. Pathological evaluation is essential for prognostication which includes histological typing, grading, staging, there by assisting in further management of patients. ${ }^{2,3}$ Knowledge of a particular disease pattern in the local population is not only important to monitor the people at risk, but also to impart valuable information that could be used for treating patients as well as to plan and implement various health programmes. ${ }^{3}$ The present study was undertaken over a period of 5 years at a tertiary rural health care center in south India to analyze the pattern of the disease encountered at our hospital setup and to compare the findings with studies done in rest of India and other neighboring countries. The present study can be utilized as a baseline, for future studies to analyze the trends of renal diseases over time in this region.

\section{Materials and Methods}

Following clearance from the institutional Ethics committee, this 5 year retrospective and prospective study was done on all nephrectomies specimens received from January 2012 to December 2017. Core needle biopsy and pelvi-ureteric junction specimens were excluded from the study. Clinical autopsy specimens received at department were also included for the study. Relevant data that included clinical and laboratory findings were obtained from the histopathology request forms and case files. All nephrectomy specimens in this study were received in $10 \%$ formalin and were grossed according to standard grossing protocols. After routine processing, $4-5 \mu \mathrm{m}$ thick sections were cut and routinely stained with haematoxylin and eosin stain. The final diagnosis was confirmed by correlating the clinical, radiological, gross and microscopic findings. Special stains and immunohistochemistry were used wherever required.

\section{Results}

Total of 38 renal specimens were examined over a period of five years (from January 2012 to December 2017). Out of the 38 cases studied 25 were from males (68\%) and 13 from females cases (31\%). The male: female ratio thus was 1.9:1. The youngest was 2 years old case of Wilm's tumor and the oldest was 70 years old a case of clear cell carcinoma. A majority of nonneoplastic lesions were seen in the age group of 31-50 years, while most neoplastic lesions fell into the age group of 51-60 years. Peak incidence was seen in the 5th decade, 15 cases $(39.4 \%)$ followed by 4 th decade 10 cases $(26.3 \%)$ as depicted in table 1. 
Table 1: Age and sex wise distribution of all nephrectomies patients.

\begin{tabular}{|c|c|c|c|}
\hline Year & Male & Female & Total \\
\hline $0-10$ & 1 & - & 1 \\
\hline $11-20$ & 0 & 0 & 0 \\
\hline $21-30$ & 1 & 1 & 2 \\
\hline $31-40$ & 6 & 2 & 8 \\
\hline $41-50$ & 6 & 4 & 10 \\
\hline $51-60$ & 10 & 5 & 15 \\
\hline $61-70$ & 1 & 1 & 5 \\
\hline Total & $\mathbf{2 5}(\mathbf{6 5 . 7 \% )}$ & $\mathbf{1 3}(\mathbf{3 4 . 2 1 \%})$ & $\mathbf{3 8}$ \\
\hline
\end{tabular}

Table 2: Histopathological distribution of various renal lesions

\begin{tabular}{|l|c|c|}
\hline Histopathological diagnosis & No of cases & Percentage \\
\hline Non- Neoplastic & & \\
\hline Chronic pyelonephritis & 10 & $26.31 \%$ \\
\hline Xanthogranulomatous pyelonephritis & 1 & $2.6 \%$ \\
\hline Hydronephritis & 3 & $7.89 \%$ \\
\hline Infectious (pyonephritis) & 3 & $7.89 \%$ \\
\hline Nephrosclerosis & 3 & $7.89 \%$ \\
\hline Acute tubular necrosis & 1 & $2.6 \%$ \\
\hline Total & $\mathbf{2 1}$ & $\mathbf{5 5 . 2 6 \%}$ \\
\hline Neoplastic & & \\
\hline Benign & 1 & \\
\hline Solitary fibrous tumor & 1 & $2.6 \%$ \\
\hline Angiomyolipoma & 1 & $2.6 \%$ \\
\hline Renaloncocytoma & & \\
\hline Malignant & 11 & $28.94 \%$ \\
\hline Renal cell carcinoma & 1 & $2.6 \%$ \\
\hline Wilm's tumor & 1 & $2.6 \%$ \\
\hline TCC of Renal pelvis & 1 & $2.6 \%$ \\
\hline TCC with chronic pyelonephritis & $\mathbf{1 7}$ & $\mathbf{4 4 . 7 3 \%}$ \\
\hline Total & & \\
\hline
\end{tabular}

As depicted in table 2 majority of nephrectomies were of the non-neoplastic category (21 cases, $55.26 \%$ ).

Among the non-neoplastic lesions chronic pyelonephritis was the commonest histopathological condition $(26.31 \%)$. Three cases $(7.89 \%)$ each of hydronephrosis, nephrosclerosis and pyonephrosis secondary to (hydatid disease, tuberculosis, candida infection) were seen. One case each $(2.6 \%)$ of xanthogranulomatous pyelonephritis, acute tubular necrosis were observed. Grossly cases with chronic pyelonephritis were had varying sized coarse depressed scars and dilated to distorted pelvicalyceal system. Microscopically there was varying degrees of glomerular atrophy, hyalinization, periglomerular fibrosis along with tubular atrophy, chronic interstitial inflammation and thickened blood vessels.

Out of the 38 cases, 17 cases were neoplastic (44.73\%), 14 (36.84\%) were malignant and $3(7.89 \%)$ were benign. Renal cell carcinoma was the most common neoplasm (11 cases $28.94 \%$ ). Two cases (5.2\%) of urothelial carcinoma and one case (2.6\%) of Wilm's tumor was also encountered. Patients with renal cell carcinomas were seen in the 41-70 years age group with a definite peak in $5^{\text {th }}$ decade $(39.43 \%)$ followed by $4^{\text {th }}$ decade $(26.31 \%)$. The male to female ratio was 1.9:1. Of the 11 cases of renal cell carcinoma 8 cases $(21 \%)$ involved the upper pole while 3 cases $(7.89 \%)$ were large tumor having a rim of peripheral renal parenchyma, tumor size was in the range of $4-12 \mathrm{~cm}$. The growths had a variegated appearance with a yellowish cut surface and large areas of hemorrhage and necrosis. On microscopy, clear cell variant ( 8 cases $21.05 \%$ ) was the most common histological type. Two cases (5.26\%) were of papillary type, and one case (2.6\%) of chromophobe type. Fuhrman nuclear grading revealed showing Grade 2 nuclear features $9(23.68 \%)$ cases and Grade 3 nuclear features in $2(5.2 \%)$ cases.

Two cases $(5.2 \%)$ of urothelial carcinoma encountered. Both were seen in males. Of these 2 cases, one case involved renal pelvis. One case of Wilm's tumor in a 2 year old male child was encountered. Grossly the tumor was nodular with areas of hemorrhage. Microscopically, it showed triphasic lineage having blastemal, epithelial and mesenchymal components. Three out of 38 cases $(7.89 \%)$ were benign tumors. One of these was an angiomylipoma (2.6\%) that was seen in 45 year female without features of tuberous sclerosis. It showed a variable mixture of spindle shaped 
cells, adipose tissue and blood vessels. One case of renal oncocytoma $(2.6 \%)$ with solid grey brown cut surface was seen showing an alveolar or tubular pattern on microscopy. Tumor was composed of polygonal cells with smooth contours having a round to oval nucleus and an intensely eosinophilic granular cytoplasm. A rare case (2.6\%) of benign solitary fibrous tumor in a 60 year female was encountered. Grossly this tumor was bosselated and well circumcised. It had firm grey white cut surface. A rim of renal parenchyma was noted in the periphery at one pole. Microscopically it showed a cellular neoplasm composed of bland spindle cells in storiform pattern of arrangement. Foci of collagenization and a mild stromal chronic inflammatory cell infiltrate were also noted.

Clinical Presentation: The common clinical presentation observed among the 38 cases studied were flank pain, hematuria, abdominal lump followed by fever.

Table 3: Distribution and comparison of nephrectomy specimens according to histopathological lesions with other studies

\begin{tabular}{|c|c|c|c|c|c|c|}
\hline $\begin{array}{l}\text { Histopathological } \\
\text { diagnosis }\end{array}$ & $\begin{array}{c}\text { Present } \\
\text { study } \\
(2012-2017) \\
\text { Bangalore } \\
\end{array}$ & $\begin{array}{l}\text { Reddy KD et } \\
\text { al (2014-2016) } \\
\text { Hyderabad }\end{array}$ & $\begin{array}{c}\text { Shaila et al } \\
(2010-2015) \\
\text { Kurnool }\end{array}$ & $\begin{array}{c}\text { Aiffa et al } \\
(2005-2010) \\
\text { Srinagar }\end{array}$ & $\begin{array}{c}\text { Swarnalata } \\
\text { et al } \\
\text { (2011-2015) } \\
\text { Rajasthan } \\
\end{array}$ & $\begin{array}{c}\text { Ibrahim et al } \\
(1991-2000) \\
\text { Jordan }\end{array}$ \\
\hline \multicolumn{7}{|l|}{ Non- Neoplastic } \\
\hline Chronic pyleonephrites & $10 /(26.31 \%)$ & $33 /(42.9 \%)$ & $64 /(60.38 \%)$ & $88 /(62.8 \%)$ & $17 /(44.7 \%)$ & $117 /(27.1 \%)$ \\
\hline $\begin{array}{l}\text { Xanthogranulomatous } \\
\text { pyelonephritis }\end{array}$ & $1 /(2.6 \%)$ & $8 /(10.4 \%)$ & $2 /(1.89 \%)$ & $8 /(5.7 \%)$ & $1 /(2.6 \%)$ & $13 /(3.01 \%)$ \\
\hline Hydronephritis & $3 /(7.89 \%)$ & $10(12.9 \%)$ & - & - & $7 /(18.4 \%)$ & - \\
\hline $\begin{array}{l}\text { Infectious } \\
\text { (pyonephritis) }\end{array}$ & $3(7.89 \%)$ & $6(7.8 \%)$ & $12(11.32 \%)$ & $5 /(3.5 \%)$ & $1 /(2.6 \%)$ & $17 /(3.94 \%)$ \\
\hline Nephrosclerosis & $3(7.89 \%)$ & - & - & & - & - \\
\hline Acute tubular necrosis & $1(2.6 \%)$ & - & - & & - & - \\
\hline others & & $5(6.49 \%)$ & $4(3.78 \%)$ & $6 /(6.81 \%)$ & - & $121(28.6) \%$ \\
\hline Total & $21 /(55.2 \%)$ & $62 /(80.5 \%)$ & $82 /(77.6 \%)$ & $107 /(63.5 \%)$ & $27 /(41.5 \%)$ & $268 /(63.3 \%)$ \\
\hline \multicolumn{7}{|l|}{ Neoplastic } \\
\hline Benign & $3 /(7.89 \%)$ & $2 /(5.9 \%)$ & $4 /(3.77 \%)$ & $1 /(0.7 \%)$ & $1 /(0.7 \%)$ & $30 /(7.1 \%)$ \\
\hline Solitary fibrous tumor & $1(2.6 \%)$ & & - & - & - & - \\
\hline Angiomyolipoma & $1(2.6 \%)$ & $1(1.3 \%)$ & - & $1 /(0.7 \%)$ & - & - \\
\hline Renal oncocytoma & $1(2.6 \%)$ & $1(1.3 \%)$ & $2(1.84 \%)$ & - & $1 /(2.6 \%)$ & - \\
\hline others & & & $2(1.84 \%)$ & - & - & - \\
\hline Malignant & $14(36.8 \%)$ & $13 /(16.9 \%)$ & $20(18.86 \%)$ & $32(22.8 \%)$ & $38 /(58.4 \%)$ & $125(29.6 \%)$ \\
\hline Renal cell carcinoma & $11(28.94 \%)$ & $8 /(10.4 \%)$ & $12 /(63.16 \%)$ & $25 /(17.8 \%)$ & $30 /(78.94 \%)$ & $91 /(21.5 \%)$ \\
\hline Wilm's tumor & $1(2.6 \%)$ & $3(3.9 \%)$ & $5 /(26.36 \%)$ & $5 /(3.5 \%)$ & $3 /(7.89 \%)$ & $21 /(5.0 \%)$ \\
\hline TCC of Renal pelvis & $1(2.6 \%)$ & - & & - & & \\
\hline $\begin{array}{l}\text { TCC with chronic } \\
\text { pyelonephritis }\end{array}$ & $1(2.6 \%)$ & - & $1 /(0.94 \%)$ & - & $2 /(5.26 \%)$ & $6 /(1.4 \%)$ \\
\hline others & - & $2 /(2.6 \%)$ & $2 /(1.88 \%)$ & $2 /(1.4 \%)$ & $3 /(7.8) \%$ & $7 /(1.7 \%)$ \\
\hline Total & $17(44.7 \%)$ & $15(19.5 \%)$ & $24(22.6 \%)$ & $33(23.5 \%)$ & $39(59.16 \%)$ & $155(36.7 \%)$ \\
\hline
\end{tabular}

Fig 1 a. Gross solitary fibrous tumoe; (b): Solitary fibrous tumor (40X); (c): Clear cell variant of RCC (40X); (d): Renal Oncocytoma (40X) 

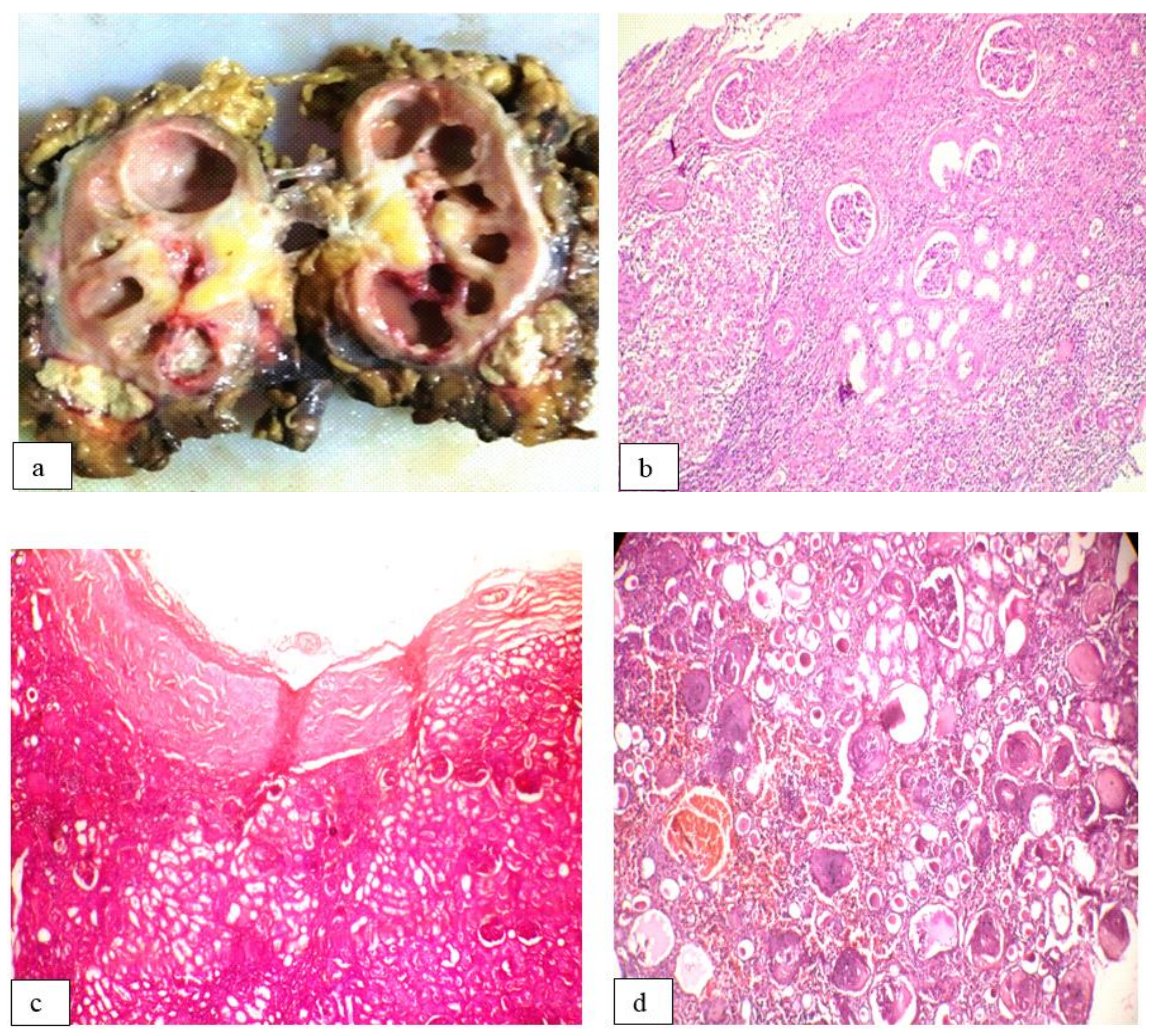

Fig. 2 (a): Gross tuberculous pyelonephritis; (b): Tuberculous pyelonephritis (40X); (c): Renal hydatid cyst (40X); (d): Chronic pyelonephritis (40X)

\section{Discussion}

The Analysis of 38 cases of nephrectomy was done in 5 years study period. Out of the 38 cases, 21 cases $(55 \%)$ were non- neoplastic and 17 cases $(42.1 \%)$ were neoplastic lesions. There were more number of nonneoplastic lesions, which is comparable to studies done by other national and international studies such as Reddy KD et al, ${ }^{4}$ Shaila et al, ${ }^{5}$ Aiffa et al, ${ }^{6}$ and Ghalayini IF et $\mathrm{al}^{7}{ }^{7}$ where non-neoplastic lesions were $80.5 \%, 77.66 \%$, $63.5 \%, 63.3 \%$ and the neoplastic lesions were $19.5 \%$, $22.64 \%,{ }^{4} 22.8 \%, 29.6 \%$ respectively.

On the contrary, Swarnalata Ajmera et $\mathrm{al},{ }^{8}$ had encountered more neoplastic (60\%) as to non- neoplastic lesions (40\%). Among the 38 cases 25 cases $(65 \%)$ were of males and 13 cases (34\%) were of females. The male: female ratio in this study is 1.9:1, which is in concurrence with a study done on 50 cases by Latihf et $\mathrm{al}^{9}$ who found a similar ratio of 1.9:1.

Peak incidence of renal diseases in this study was seen in $5^{\text {th }}$ decade $(39.4 \%)$ followed by $4^{\text {th }}$ decade (26.3\%). This is similar to studies done by Shaila et al and Swarnalata Ajmera et $\mathrm{al}^{5,8}$ who have reported incidences of $26.41 \%$ and $29.2 \%$ in the $5^{\text {th }}$ and $18.86 \%$, $26.1 \%$ in the $4^{\text {th }}$ decade respectively. Muhammed et al, $\&$ Suryawanshi et al ${ }^{10,11}$ observed a peak incidence in $3^{\text {rd }}$ decade $(30 \%),(24.5 \%)$ followed by $4^{\text {th }}$ decade $(20 \%)$, (24.5\%). Cultural and environmental factors like hot \& humid conditions of these places might have contributed for lower age occurrence.
The most common indication for nephrectomy in our study was chronic pyelonephritis (10 cases $26.31 \%$ ). This is similar to other studies done in literature. ${ }^{4-6,12}$ But Swarnalata Ajmera et $\mathrm{al}^{8}$ who analyzed 65 cases found neoplastic $(58.46 \%)$ etiology to be the most common clinical indication for nephrectomy. Geographic variation has been found in the indications for nephrectomies in different studies around the globe owing to variation in the pattern of renal diseases encountered. Since our hospital is a tertiary care centre catering to poor illiterate rural patients, more number of patients have come for treatment in advanced renal conditions. Increased prevalence of non-neoplastic lesions in this region, triggers the bell to initiate screening programmes for early intervention and management of chronic renal diseases. This would reduce the need for nepherctomies in non- neoplastic category.

We encountered 3 cases $(7.89 \%)$ each of hydronephrosis, nephrosclerosis and pyonephritis (secondary to (hydatid disease, Candia, Tuberculosis), similar finding were found in study done by Ghalayini IF et al. ${ }^{7}$

On the contrary, other studies observed more number of nephrosclerosis, namely Reddy KD et al (15.7\%), Muhammad et al, (17.39\%), Ashima et al $(12.9 \%),{ }^{4,10,13}$ A higher number of tubercular pyelonephritis cases was observed by Reddy $\mathrm{KD}$ et al (7.8\%) and Shaila et al, $(11.32 \%)^{4,5}$ unlike our study where only one case $(2.6 \%)$ was encountered. All other 
studies had larger sample size compared to our study, this might have contributed in increased number of hydronephrosis, nephrosclerosis and pyonephrosis cases compared to our study. One rare case of Candia infection with chronic pyelonephritis in an 55 year female immunocompromised patient, and a case of renal hydatid cyst in a migratory 45 year old female labourer were encountered. Hydatid disease is not a commonly seen disease in this region. And renal involvement by hydatid disease is even rarer seen in only $3 \%-5 \%$ of patients as reported in literature. Xanthogranulomatous pyelonephritis has been observed commonly in females as reported by Ghalayini IF, Siddapa et al et al. ${ }^{7,14} \mathrm{We}$ encountered only one case in a 33 year old female patient and hence no meaningful conclusion can be made on the female predilection noted by the others.

In the present study, a total of $16(44.7 \%)$ malignant lesions were reported, of this majority of comprised renal cell carcinomas, \& transitional cell carcinoma combined. Similar findings were reported by Datta et a ${ }^{15}$ ( 113 cases 94\%). Mohammad Rafique et al ${ }^{16}$ (36 cases, $97 \%$ ) also observed that majority of malignant neoplasms of the kidney were renal cell carcinomas. ${ }^{12}$ Among the renal cell carcinomas majority of cases were seen males $8(21 \%)$ and $3(3.8 \%)$ were in females. Left sided involvement was slightly more (8 cases) than right side (5 cases). This finding was similar to that observed by Swarnalata Ajmera et al. ${ }^{8}$

In our study out of 11 cases (28.94\%), microscopically, the clear cell type of renal cell carcinoma was the predominant type of tumor involving 8 cases $(21.05 \%)$, followed by papillary type in 2 cases $(5.26 \%)$. Similar observation have been noted by Aiffa et al and Mahesh Kumar et al. ${ }^{6,17}$ Fuhrman nuclear grading revealed

$9(23.68 \%)$ cases showing Grade 2 nuclear features and $3(7.89 \%)$ cases with Grade 3 nuclear features. Thus, majority of cases (31.4\%) showed Grades 2 and 3 nuclear features. These findings are in concurrence with a study done by Popat et $\mathrm{al}^{12}$ who observed that all cases of conventional renal cell carcinomas showed Grades 2 and 3 nuclear features.

Table 4: Histological types of renal cell carcinoma in different studies

\begin{tabular}{|l|c|c|c|}
\hline & $\begin{array}{c}\text { Mahesh Kumar et } \\
\text { al (7 cases) }\end{array}$ & $\begin{array}{c}\text { Aiffa Aimann et al } \\
\text { (25 cases) }\end{array}$ & $\begin{array}{c}\text { Present Study (11 } \\
\text { cases) }\end{array}$ \\
\hline Clear cell type & $57.19 \%(4)$ & $80 \%(20)$ & $21.05 \%(8)$ \\
\hline Papillary type & $14.2 \%(1)$ & $12 \%(3)$ & $5.26 \%(2)$ \\
\hline Granular type & $14.2 \%(1)$ & $8 \%(2)$ & 0 \\
\hline Sarcomatoid type & $14.2 \%(1)$ & 0 & 0 \\
\hline Chromophobe type & 0 & 0 & $1(2.6 \%)$ \\
\hline
\end{tabular}

We observed one case $(2.6 \%)$ of Wilm's tumor and 2 cases $(3.2 \%)$ of transitional cell carcinoma in our study, Ghalayini IF et $\mathrm{al}^{7}$ encountered more number of Wilm's tumor and he observed 2 cases $(5.2 \%)$ of transitional cell carcinoma tumors in his study. Among the 3 benign neoplasm (7.89\%) encountered, one case each of angiomyolipoma without tuberous sclerosis, renal oncocytoma, benign solitary fibrous tumor were noted. Reddy $\mathrm{KD}$ et $\mathrm{al}^{4}$ also observed a similar distribution of angiomyolipoma and renal oncocytomas.

\section{Conclusion}

Nephrectomies done for non-neoplastic lesions were more common than neoplastic lesions of the kidney. Chronic pyelonephritis was the commonest lesions in the series with male predominance and renal cell carcinoma was the commonest malignant tumor. Rare cases encountered were that of renal hydatid cyst, solitary fibrous tumor and transitional cell carcinoma of renal pelvis. Implementation of extensive education and screening programmes along with early intervention and management of common conditions like diabetes mellitus, hypertension, and renal calculi will definitely reduce the indication for nephrectomies in nonneoplastic lesions. This baseline data can be utilized for further studies in future to evaluate the trends of renal diseases in this region.

\section{References}

1. Novick AC, Streem SB, Surgery of the kidney, Walsh PC, Retik AB, Stamey TA, Vaughan ED Campbell's Urology Vol-3 6th ed. WB Saunders;p2428-2435.

2. Rahul Mannan. Comparative Analysis of a Retrospective Vs Prospective Study Ascertaining Spectrum of Renal Lesions: Experience of a Tertiary Care Teaching Centre in North India. American Journal of Medicine and Medical Sciences. 2015;5(2):105-111.

3. Vikram Narang et al Histomorphological Spectrum of Nephrectomy Specimens- A Tertairy Care Centre Experience. National Journal of Laboratory Medicine. 2016;5(2):51-54.

4. Reddy KD, Gollapalli SL, Chougani S et al. A clinicomorphological spectrum of nephrectomy specimens - an experience from a tertiary care hospital. Int J Health Sci Res. 2016;6(11):67-72.

5. Shaila, Nityananda BS, Tamil Arasi. Spectrum of lesions in nephrectomy specimens in tertiary care hospital. Journal of evolution of Medical and Dental Sciences. 2015;4(73):12714-12726.

6. Aiman A, Singh K, Yasir M. Histopathological spectrum of lesions in nephrectomy specimens: A five-year experience in a tertiary care hospital. $J$ Sci Soc. 2013;40:148-54.

7. Ghalayini IF. Pathological spectrum of nephrectomies in a general hospital. Asian J Surg. 2002;25:163-9. 
8. Ajmera S, Ajmera R. Histopathological spectrum of lesions in nephrectomies -a five year study. Int $J$ Health Sci Res. 2017;6(7):44-46.

9. Latif F, Mubarak M, Kazi JI. Histopathological characteristics of adult renal tumors: a preliminary report. J Pak Med Assoc. 2011;61:224-8.

10. Muhammad Akmal, Khizar Ishtiaque Khan, Shahid Rana, Nephrectomy-an Overview, Pak J Surj. 2012:28(2):102105 .

11. Suryawanshi. Histomorphological Analysis of Lesions in Nephrectomy Specimens: A 4 Years Study In A Rural Hospital In India-Our Experience. Annals of Pathology and Laboratory Medicine. 2017;4(3):231-235

12. Popat VC, Kumar MP, Udani D, Mundra MP, Vora DN, Porecha MM. A study on culprit factors ultimately demanding nephrectomy. Internet J Urol. 2010; 7.

13. Ashima N Amin, Pushpalatha Pai, Krishnaraj Upadhyaya. A Histopathological spectrum of nephrectomy specimens in a tertiary hospital in southern India. Int J Biol Med Res. 2015;6(3):5173-5178.

14. Siddappa S, Ramprasad K, Mythri Kuthagale Muddegowda. -Xanthogranulomatous pyelonephritis: A retrospective review of 16 cases. Korean J Urol. 2011:52:421-424.

15. Rafique M. Nephrectomy: Indications, complications and mortality in 154 consecutive patients. J Pak Med Assoc. 2007;57:308-11.

16. Datta B, Giri A, Halder B. Histopathological evaluation of surgically treated adult renal tumors. Indian $J$ of Cancer. 2016;53:124-26.

17. Mahesh Kumar U, Yelikar BR, Girija Patil, Mahesh H Karigoudar, Pankaj Pande and Patil SB.; Spectrum of Histopathological lesions in Nephrectomy specimens - A two year study in a tertiary care hospital. International Journal of Research in Pharmaceutical and Biomedical Sciences. 2012;3(4):1787-90.

How to cite this article: Savita D, Parthiban R. Abhishek A. Spectrum of renal lesions encountered in a rural setup over a period of five years. J Diagn Pathol Oncol. 2018;4(3):202207. 